\title{
PENGGUNAAN WASILAH DAKWAH TERHADAP ANAK-ANAK PEMULUNG WADUK PERMAI
}

\author{
Patmawati, Fitri Sukmawati dan Ibrahim
}

\begin{abstract}
Abstrak
Penelitian ini adalah penelitian participation action research (PAR), dengan pendekatan kualitatif. Sebagai penelitian PAR keterlibatan masyarakat sangat dominan karena merekalah yang mengetahui permasalahannya dan bagaimana pemecahannya (problem solving). Dalam hal ini peneliti dan tim memetakan persoalan mereka dan ikut urung rembuk dalam mencari problem solvingnya. Sehingga, dalam berdakwah bisa ditemukan wasilah yang tepat dan sesuai dengan usia anak-anak pemulung. Sebagai satu kesimpulan dari penelitian pelaksanaan dakwah keagamaan pada anak-anak pemulung Waduk Permai melalui media dakwah di Surau Ikhwanul Muslimin Kota Pontianak, didapatkan beberapa poin penting sebagai berikut: pertama, Kegiatan dakwah keagamaan melalui wasilah ini dilakukan pada anak-anak pemulung yang ada di Waduk Permai, Kota Pontianak; kedua, Kegiatan dakwah keagamaan melalui wasilah pada anakanak pemulung dapat dilaksanakan dengan baik; ketiga, Secara substansi, kegiatan dakwah keagamaan melalui wasilah telah berhasil menumbuhkan semangat keagamaan, kemandirian sikap, kekompakan anak-anak dan kecintaan mereka terhadap ilmu pengetahuan agama Islam; keempat, Pelaksanaan kegiatan dakwah keagamaan melalui wasilah pada anak-anak pemulung Waduk Permai juga telah mampu memberikan semangat dan perhatian dari para pemerhati dakwah Islam di dunia kampus khususnya IAIN Pontianak sebagai kampus negeri yang berorietasi agama.
\end{abstract}

Kata Kunci: Wasilah Dakwah, Pemulung

\section{Latar Belakang}

$$
\text { Kampung Pemulung Waduk }
$$

Permai terletak di pusat Kota Pontianak.

Dahulu, di kawasan ini ada sebuah waduk besar, dimana pemukiman para pemulung persis di pinggiran waduk bagian barat. Sedangkan di tepi sebelah timur waduk berdiri megah sebuah hotel bintang empat. Sejak tahun 2000 an, waduk ini ditutup dan digantikan dengan pembangunan ruko dan sentra ekonomi lainnya hingga menutupi sebagian besar kawasan bekas waduk sebelah utaranya. Sedangkan sebelah utara pemukiman berderet bangunan komplek perumahan mewah. Anehnya, kampung pemulung yang berada diantara bangunan mewah di sekitar kawasan waduk itu tetap ada dan dibiarkan begitu saja tampa satu kebijakan pembangunan yang berarti.

Dengan kondisi pemukiman yang kumuh, dengan iklim sosial masyarakat yang terbelakang, memberikan pemandangan yang sangat berbeda 
(kontras) dengan gedung ruko, hotel berbintang, serta komplek pemukiman mewah yang mengelilingi. Tidak adanya pasilitas pendidikan dan ibadah yang refresentatif bagi anak-anak para pemulung di kawasan ini (baik aksessibilitas dan biaya) semakin mempertegas ketertinggalan dan keterbelakangan mereka di tengah himpitan pembangunan kota. Karena kekurangan ekonomi, banyak dari anakanak usia sekolah yang tidak dapat menikmati layanan pendidikan yang wajar. Puluhan tahun mereka hidup di kawasan itu, menggantungkan diri hidup dengan memungut sampah, seolah menjadi "takdir" yang harus mereka jalani secara turun temurun, dan diwarisi dari generasi ke generasi.

Di tengah semua keprihatinan ini, ada memang pihak-pihak yang menaruh peduli terhadap kondisi masyarakat di kawasan ini, terutama bantuan insidental secara pribadi dalam bentuk sedekah dan bantuan sosial. Sementara bantuan secara terprogram dan berkelanjutan dari pemerintah belum pernah ada, termasuk pelaksanaan dakwah secara terorganisir bagi generasi anak-anak pemulung, kecuali oleh bapak Mulana yang membentuk pengajian anak-anak "Ikhwanul Muslimin". Program ini berjalan dan dikelola secara mandiri oleh bapak Mulana dalam bentuk bantuan pembelajararan Al-Qur'an, yang dimulai dari iqra, yang sudah berjalan sejak
Desember 2013. Menurut pak Mulana (pendiri pengajian anak-anak "Ikhwanul Muslimin"), murni gerakan kepedulian yang dibentuk atas panggilan pribadi untuk mendidik dan membina anak-anak dari keluarga di sekitar pemukiman pemulung Waduk Permai. Pak Mulana sendiri adalah pekerja tukang urut dan penarik becak yang nasibnya tidak jauh berbeda dengan para orang tua anakanak pemulung, namun sadar bahwa anak-anak sebagai generasi pelanjut bangsa, jangan sampai memiliki nasib yang sama dengan para orang tua mereka. Akhirnya pak Mulana sebagai pekerja tukang urut dan penarik becak tetap meluangkan waktu untuk mengajari mengaji anak-anak dari keluarga pemulung Waduk Permai ini (wawancara, 10 April 2015).

Melalui pengajian anakanak"Ikhwanul Muslimin" pak Mulana memberikan bimbingan belajar mengaji untuk anak-anak usia TK/PAUD, SD dan SMP. Secara keseluruhan ada 40 lebih anak yang ikut bimbingan belajar mengaji dalam pengajian anak-anak "Ikhwanul Muslimin". Menurut Fadilah (salah satu anak yang ikut mengaji), kegiatan bimbingan mengaji ini dilaksanakan setiap hari sehabis shalat magrib (Wawancara, 10 April 2016). Kegiatan belajar mengaji dilaksanakan di Surau Ikhwanul Muslimin, yang berada di dalam pemukiman pemulung Waduk Permai. Perhatian diberikan juga oleh sekelompok 
dosen Fakultas Ushuluddin Adab dan Dakwah (FUAD) IAIN Pontianak, selanjutnya dalam penelitian ini akan disebut sebagai dai saja, yang melaksanakan dakwah sebagai bentuk pengabdian masyarakat.

Dalam pelaksanaan dakwah, para dai menggunakan berbagai macam wasilah dakwah. Hamzah Ya'qub dalam Moh Ali Aziz (2004: 120) ${ }^{1}$ membagi wasilah dakwah menjadi lima macam, yaitu lisan, tulisan, lukisan, audio visual, dan akhlak. Oleh karena itu dalam penelitian ini fokusnya sebagai berikut: bagaimana dai menggunakan wasilah lisan, tulisan, visual, audio visual dan akhlak dalam berdakwah terhadap anakanak pemulung Waduk Permai?

\section{Tinjauan Pustaka}

\section{a. Pengertian Dakwah}

Secara bahasa, dakwah bermakna penyiaran, propaganda (W.J.S Poerwardarminta, 1976: 222). Abdul Aziz dalam Tata Sukayat (2015: 7) ${ }^{2}$ memberi makna dakwah secara bahasa bisa berarti: memanggil, menyeru, menegaskan atau membela sesuatu, perbuatan atau perkataan untuk menarik manusia kepada sesuatu, serta memohon dan meminta. Sedangkan dalam ensiklopedi Islam diartikan seruan, panggilan dan undangan (Depag RI, 1993: 231).

1 Moh. Ali Aziz, 2004, IImu Dakwah, Jakarta: Kencana, h.120.

2 Tata Sukayat, 2015, Ilmu Dakwah, Bandung: Remaja Rosdakarya.
Barangkali kita dapat sepakat, bahwa pemahaman dakwah Islam sebagai propaganda tidaklah tepat karena propaganda merupakan kegiatan dimana hasil akhirnya adalah untuk kepentingan orang yang membawa pesan tersebut (M. Arifin, 1977: 17). Sedangkan landasan dakwah bukanlah dilakukan untuk kepentingan satu golongan individu tertentu, melainkan untuk semua golongan baik minoritas maupun mayoritas.

Secara istilah dakwah itu mempunyai defenisi yang berbeda, sejalan dengan tinjauan para ahlinya. Berikut dapat diterangkan beberapa defenisi:

Dakwah ialah suatu sistem kegiatan dari seseorang, sekelompok, segolongan umat Islam sebagai aktualisasi imaniah yang memanifestasikannya kepada seseorang, sekelompok massa dan masyarakat. Supaya dapat mempengaruhi tingkah lakunya untuk mencapai tujuan tersebut (Jamaluddin Kaffie, 1993: 29). Sejalan dengan pendapat ini, Toha Yahya Umar mengemukakan bahwa dakwah adalah mengajak manusia dengan cara bijaksana menuju jalan yang benar sesuai dengan perintah Tuhan demi kebahagiaan dunia dan akhirat. ${ }^{3}$

Muhammad Nasir dalam Siti Muriah $(2000: 3)^{4}$, dakwah ialah usaha menyerukan dan menyampaikan kepada seseorang dan seluruh umat tentang

3 Toha Yahya Umar, Ilmu Dakwah, (Jakarta: Wijaya, 979), h. 1.

4 Siti Muriah, 2000, Metodologi Dakwah Kontemporer, Yogyakarta: Mitra Pustaka. 
pandangan dan tujuan hidup manusi di dunia ini yang meliputi amar ma'ruf nahi mungkar. Abu Risman mengemukakan defenisi dakwah adalah segala macam usaha yang dilakukan oleh seorang muslim atau lebih untuk merangsang orang lain agar lebih memahami, meyakini dan kemudian menghayati ajaran Islam sebagai pedoman hidup dan kehidupannya (Amrullah Ahmad, 1989: 13).

Adapun menurut Samsul Munir Amin (2014: 3$)^{5}$ dakwah ialah aktivitas yang dilakukan secara sadar untuk menyampaikan pesan-pesan agama Islam dengan menggunakan cara-cara tertentu kepada orang lain agar menerima dan menjalankannya dengan baik dalam kehidupan individual maupun sosial guna mencapai kebahagiaan dunia dan akhirat. Wahyu Ilaihi dan Harjani Hefni (2007: 1$2)^{6}$ mendefenisikan dakwah sebagai kegiatan mengajak, mendorong dan memotivasi orang lain berdasarkan bashirah untuk meniti jalan Allah dan istiqamah di jalan-Nya, serta berjuang bersama meninggikan agama Allah.

$$
\text { Dakwah adalah ajakan }
$$

sebagaimana dikemukakan di atas, dapat disimpulkan bahwa dakwah adalah ajakan, seruan, undangan dan doa yang dilakukan oleh seorang muslim atau lebih yang ditujukan kepada orang lain atau

5 Samsul Munir Amin, 2014, Sejarah Dakwah, Jakarta: AMZAH. kelompok dengan tujuan agar mereka memahami, menghayati serta mengamalkan ajaran Islam.

Pada kesempatan ini peneliti bermaksud mendefenisikan dakwah islamiyah; yaitu segala upaya yang dilakukan oleh orang muslim melalui wasilah dakwah yang ditujukan kepada suatu objek, yang mana agar mereka (muslim dan muslimah atau non muslim) kembali dan menerima serta memahami akan ajaran Islam sebagai kebenaran yang mutlak.

\section{b. Wasilah Dakwah}

Secara bahasa, wasilah berasal dari bahasa Arab yang berarti al-wuslah, al-ittisal, yaitu segala hal yang dapat mengantarkan tercapainya kepada sesuatu yang dimaksud. Menurut Ibn Manzhur, al-wasilah, bentuk jamaknya: al-wasalu dan al-wasailu yang berarti singgasana raja, derajat, atau dekat. Kata media berasal dari bahasa Latin yang secara harfiah berarti perantara, tengah atau pengantar. Dalam bahasa Inggris media merupakan bentuk jamak dari medium yang berarti tengah, antara, ratarata.

Ahli komunikasi mengartikan media sebagai alat yang menghubungkan pesan komuunikasi yang disampaikan oleh komunikator kepada komunikan

6 Wahyu Ilaihi dan Harjani Hefni, 2007, Pengantar Sejarah Dakwah, Jakarta: Rahmat Semesta. 
(penerima pesan) (Moh. Ali Aziz, 2009: 403). ${ }^{7}$ Sedangkan artinya secara istilah adalah tempat atau sarana yang digunakan untuk menyampaikan dakwah (Munawar M. Saad, 2013: 137) $)^{8}$. Tempat sebagai media dalam melaksanakan dakwah, bisa berupa mesjid, surau atau mushollah, gedung, aula dan sebagainya. Dengan demikian, wasilah dakwah adalah alat yang bersifat obyektif yang bisa menjadi saluran untuk menghubungkan ide dengan umat, suatu elemen yang vital dan merupakan urat nadi dalam totalitas dakwah yang keberadaannya sangat penting dalam menentukan perjalanan dakwah (Tata Sukayat, 2015: 27-28). Alat yang digunakan sebagai perantara untuk melaksanakan kegiatan dakwah di antaranya berupa: lisan (bahasa) (Harjani Hefni dkk. 2006: 215) ${ }^{9}$, tulisan, visual, audio visual, dan keteladanan (Muhammad Munir dan Wahyu Ilaihi, 2009: 32) $)^{10}$

Wasilah lisan, inilah wasilah dakwah yang paling sederhana yang menggunakan lidah dan suara, dakwah dengan wasilah ini dapat berbentuk pidato (khitabah) (Dindin Solahuddin, 2004: 12) $)^{11}$, ceramah, kuliah, bimbingan, penyuluhan, dan sebagainya (Moh. Ali

7 Moh. Ali Aziz, 2009, IImu Dakwah, Jakarta: Kencana.

8 Munawar M. Saad, Dasar-dasar IImu Dakwah, 2013, Pontianak: STAIN Pontianak Press, 137.

9 Harjani Hefni dkk. 2006, Metode Dakwah, Jakarta: Prenada Media.
Aziz, 2004: 120). Dalam hal ini, dai mentransfer informasi kepada orang lain, baik perseorangan maupun berkelompok sebagai suatu proses sosial secara berhadapan langsung dengan wasilah lisan (Zaini Muchtarom, 1996: 88). Dengan demikian dakwah bi lisan adalah memanggil, menyeru ke jalan Tuhan untuk kebahagian dunia dan akhirat dengan menggunakan bahasa (Harjani Hefni dkk., 2006: 215).

Dakwah dengan wasilah lisan dalam bentuk khitabah berfungsi sebagai wahana sosialisasi dan transformasi ajaran Islam. Dai mensosialisasikan ajaran Islam yang "membumi" bukan ajaran Islam yang berada di dunia "awanawan". Oleh karena itu, dai mensosialisasikan ajaran Islam yang sudah ditransformasikan dari sifat tekstualnya menjadi kontekstual (Dindin Solahudin, 2004: 16).

Wasilah lisan dalam bentuk bimbingan (irsyad) atau konseling. Irsyad berasal dari bahasa Arab rasyada, artinya mencari petunjuk ke jalan yang lurus lawan dari kata sesat. Irsyad artinya proses membantu seseorang dalam mengatasi permasalahan pribadinya dengan mengarahkan dirinya untuk mengatasi masalah dirinya sendiri.

10 Muhammad Munir dan Wahyu Ilaihi, 2009, Manajemen Dakwah, Jakarta: Kencana.

11 Dindin Solahudin, 2004, Komunikasi \& Penyiaran Islam, 2004, Bandung: Benang Merah Press, h.12. 
Sedangkan konseling berasal dari bahasa Inggris "to consul" yang secara etimologi berarti "to give advice" atau member saran dan nasehat. Rogers dalam M. Edi Kurnanto (2015: 2) $)^{12}$ mengatakan bahwa konseling adalah serangkaian pertemuan langsung dengan individu yang diarahkan untuk membantunya dalam mengubah sikap dan perilakunya. Dari makna di atas, dapat dipahami bahwa irsyad atau konseling mengandung arti menunjukkan jalan yang lurus dan membimbing orang yang tersesat untuk kembali ke jalan yang lurus dengan memaksimalkan potensi yang ada pada orang yang dibimbing (Harjani Hefni, 2014: 138) ${ }^{13}$.

Wasilah tulisan, bisa berupa surat menyurat, buku majalah, surat kabar, spanduk dan sebagainya. Wasilah tulisan sudah dilaksanakan Rasulullah dalam bentuk Piagam Madinah, adalah sebuah perjanjian untuk mengatur berbagai kepentingan dalam masyarakat multi etnis, suku, dan agama. Banyak peneliti menganggap bahwa Piagam Madinah adalah sebuah terobosan dan prestasi nabi yang sangat modern. Sebab dengan piagam itu, nabi mampu mempersatukan masyarakat yang sebelumnya hidup dengan fanatisme suku dan kabilah, antara satu suku dan suku lainnya saling bermusuhan dan saling ingin

12 M. Edi Kurnanto, 2015, Bimbingan \& Konseling Keagamaan, Pontianak: IAIN Pontianak Press. meniadakan. Noercholish Madjid (1983: 11) menyebut:

Bunyi naskah Konstitusi itu sangat menarik. la memuat pokok-pokok pikiran yang dari sudut tinjauan modern pun mengagumkan. Dalam konstitusi itulah untuk pertama kalinya dirumuskan ide-ide yang kini jadi pandangan hidup modern, seperti kebebasan beragama, hak setiap kelompok untuk mengatur hidup sesuai dengan keyakinannya, kemerdekaan hubungan ekonomi dan lain-lain. Tetapi juga ditegaskan adanya suatu kewajiban umum, yaitu partisipasi dalam usaha pertahanan bersama menghadapi musuh dari luar.

Wasilah bashariyah (Tata Sukayat: 2015, 29) atau visual media pandang, artinya bisa dilihat). Wasilah ini bisa dalam bentuk pers, majalah, surat, poster atau plakat, buku, internet, SMS (Short Message Service), dan brosur (Moh. Ali Aziz, 2009: 413-423). Adapun media audio visual (media dengar pandang, artinya bisa didengar sekaligus dipandang). Bentuknya bisa berupa televise, film, sinema elektronika dan lainlain.

Wasilah dakwah melalui keteladanan. Perilaku nabi Muhammad memberikan pengaruh kuat pada kehidupan masyarakat muslim, karena perilaku nabi menjadi bahagian dari

\footnotetext{
13 Harjani Hefni, 2014, Komunikasi Islam,
} Pontianak: IAIN Press. 
ajaran Islam yang ditempatkan sebagai sumber kedua setelah al-Quran. Pengakuan ini bukan hanya datang dari kalangan Islam, tetapi juga para peneliti dari luar, misalnya Philip K. Hitti (1974: 120). la mengakui bahwa perilaku nabi sudah menjadi panutan jutaan manusia di bumi. Hitti selanjutnya menulis: Perilaku kesehariannya...telah membentuk satu tatanan norma yang ditaati oleh jutaan orang dewasa ini. Tidak ada seorang pun perilakunya yang ditiru sedemikian detail oleh sejumlah besar manusia selain Muhammad, seorang Manusia Sempurna.

\section{Metode Penelitian}

Penelitian ini adalah penelitian participation action research (PAR), dengan pendekatan kualitatif. Sebagai penelitian PAR keterlibatan masyarakat sangat dominan karena merekalah yang mengetahui permasalahannya dan bagaimana pemecahannya (problem solving). Dalam hal ini peneliti dan tim memetakan persoalan mereka dan ikut urung rembuk dalam mencari problem solvingnya. Sehingga, dalam berdakwah bisa ditemukan wasilah yang tepat dan sesuai dengan usia anak-anak pemulung. Untuk tercapai hasil penelitian ini di lapangan, ada beberapa langkah yang akan dilakukan oleh peneliti dan tim, antaranya adalah:

1. Membangun komunikasi dan
silaturahmi yang baik dan

berkelanjutan kepada masyarakat pemulung di kawasan Waduk Permai, terutama pada tokoh- tokoh masyarakatnya, para orang tua, maupun para anak mudanya. Melalui komunikasi seperti inilah akan dimungkinkan terbangunnya situasi komunikasi dan hubungan sosial yang baik dan saling percaya, yang dengannya peneliti akan dapat melihat dan mendengar setiap harapan dan keinginan mereka, rencana masa depan mereka dan generasi anak-anaknya. Kunjungan untuk komunikasi dan silaturrahmi semacam ini sudah dilakukan beberapa kali, bahkan menjadi dasar bagi perencanaan pelaksanaan penelitian ini secara partisipatif.

2. Mengadakan beberapa seri pembinaan keagamaan dan wawasan keislaman kepada para pemulung di kawasan Waduk Permai, baik pada orang-orang tua melalui pengajian dan bimbingan keislaman, maupun pada anak-anaknya melalui program pembinaan keagamaan di surau Ikwanul Muslimin.

3. Memberikan penguatan dan pendampingan terhadap para dosen yang melakukan dakwah keagamaan sebagai bentuk pengabdian masyarakat melalui pelatihan mental (kekuatan psikologi) dan spiritual (semangat keagamaan) dalam menghadapi segala tantangan dan 
hambatan kerja (pengabdian) di lapangan.

4. Membangun kerjasama kemitraan terhadap pihak pemerintah Perguruan Tinggi (khususnya LP2M dan Fakultas Ushuluddin, Adab, dan Dakwah IAIN Pontianak), Bimbingan Konseling "Baiti Jannati" dan Lembaga Psikolog Ghandur dalam rangka meningkatkan pembinaan keagamaan dan mental pada komunitas pemulung di kawasan Waduk Permai, Kota Pontianak.

5. Secara keseluruhan, penelitian PAR yang dilakukan dalam dakwah keagamaan ini meliputi enam langkah (proses kerja), yakni: komunikasi pendahuluan (observasi dan wawancara awal), diskusi dan pemetaan masalah, perencanaan dakwah dan wasilahnya, pelaksanaan program dakwah dan wasilahnya, evaluasi, dan pelaporan atau tindak lanjut. Berikut bagan alur proses kerja penelitian di lapangan.
Bagan: 1

Alur Proses Pelaksanaan Dakwah di Lapangan

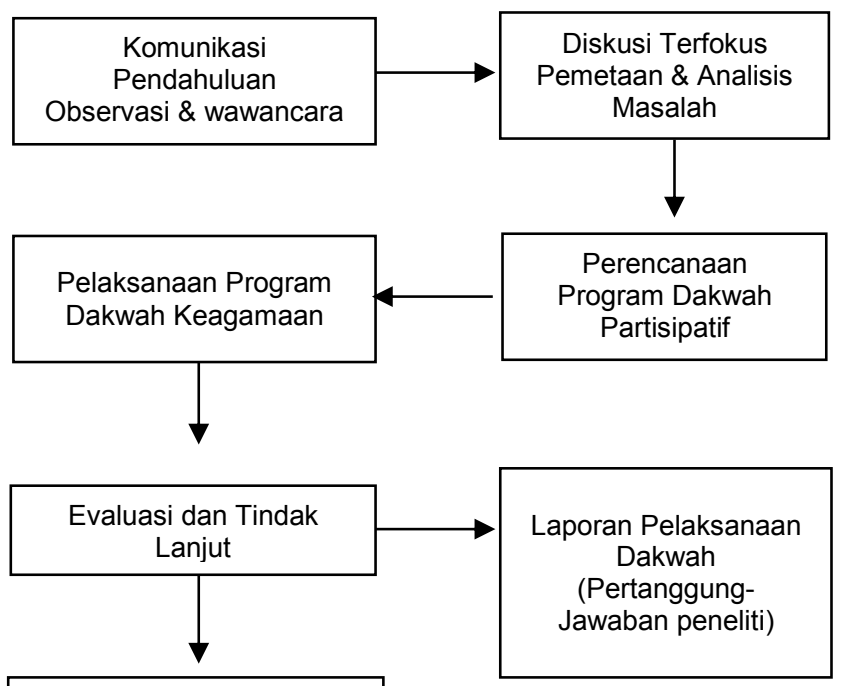

Dakwah Lanjutan

Legenda:

a. Komunikasi Pendahuluan dilakukan sejak pertama kali peneliti dan tim akan merencanakan penelitian ini, dalam bentuk observasi dan wawancara awal kepada guru ngaji anak-anak dan pengurus surau Ikhwanul Muslimin.

b. Diskusi Terfokus dilakukan bersamasama dengan guru ngaji dan para pengurus surau Ikhwanul Muslimin tentang persoalan-persoalan keagamaan yang dialami anak-anak pemulung.

c. Perencanaan Program Pembinaan Partisipatif dilakukan bersama para stakeholder di lapangan mengenai dakwah apa yang diperlukan dan penting serta wasilah apa yang digunakan untuk diberikan kepada 
anak-anak, khususnya anak-anak pemulung di pemukiman Waduk permai.

\section{d. Pelaksanaan Dakwah Keagamaan} yang merupakan inti (substansi) dari kegiatan dakwah ini, dimana kegiatan dakwah tersebut merupakan hasil dari diskusi dan perencanaan partisipatif terhadap pembinaan keagamaan yang diperlukan.

Evaluasi dan Rencana Tindak Lanjut merupakan Rangkaian kegiatan akhir dari program ini secara resmi, dimana setelah ini peneliti dan tim akan membuat laporan sebagai pertanggung-jawaban terhadap realisasi kerja penelitian dakwah keagamaan di lapangan, sebaliknya bagi anak-anak akan ditentukan kegiatan dakwah dan wasilahnya sebagai tindak lanjut yang akan dilakukan secara berkesinambungan dan mandiri.

\section{Hasil penelitian dan pembahasan}

1. Dakwah melalui wasilah lisan dan audio visual

Semua dai yang turun ke Waduk Permai melaksanakan dakwahnya terhadap anak-anak pemulung dengan menggunakan wasilah lisan di samping wasilah lainnya. Wasilah lisan dipakai disaat memulai dakwah dan menjelaskan adegang-adegang yang ditayangkan

14 Suasana dakwh keagamaan dengan tema motivasi beragama yang diberikan pertama kali dalam kegiatan dakwah ini. melalui audio visual serta dai mengakhiri ceramah dengan menyimpulkan inti pesan-pean dakwah.

Salah satu dai (H. Fitri Sukmawati) yang menggunakan wasilah lisan dan audio visual. Beberapa hal yang menjadi fokus perhatian dalam materi ini antara lain pentingnya kesadaran diri dalam beragama, alasan pentingnya mengetahui bacaan shalat dengan menggunakan media film dengan judul Hapalan Shalat Delisa.

Gambar:

Pelaksanaan Dakwah Melalui Motivasi Beragama $^{14}$
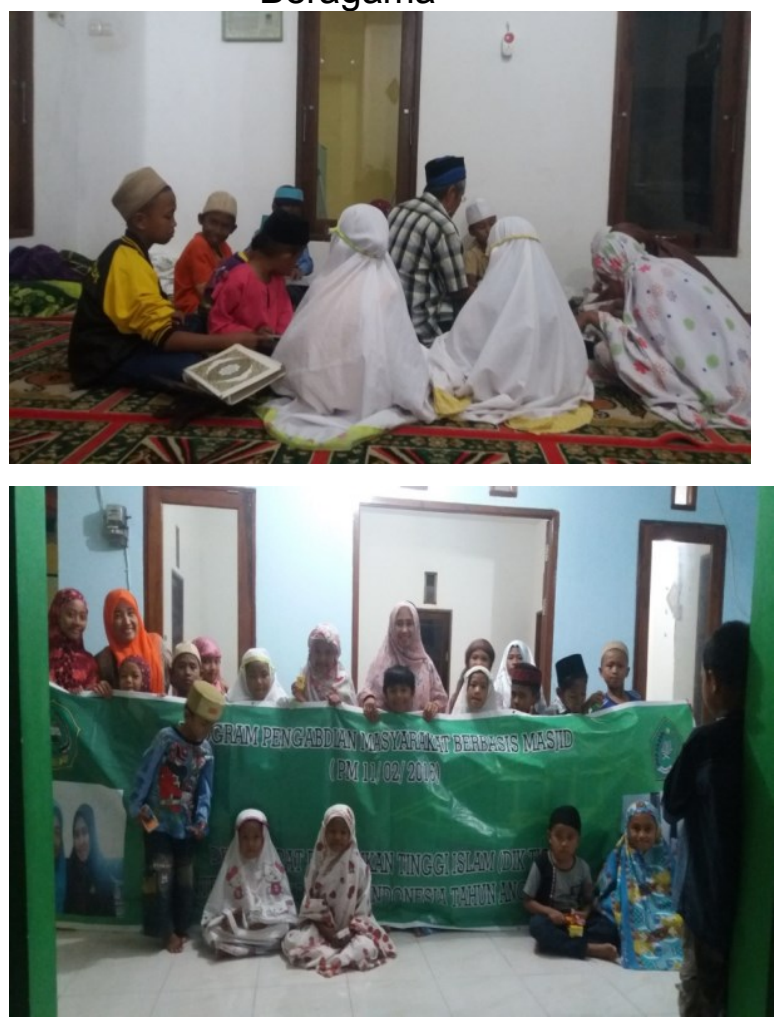

Sumber: Dokumen Kegiatan dakwah

Tampak suasana meriah dan penuh antusiasme dari anak-anak pemulung Waduk Permai. 
Intinya bahwa, melalui materi ini pemateri berharap munculnya kesadaran yang baik pada anak-anak pemulung dalam beragama, khususnya pelaksanaan ibadah shalat. Anak-anak menyadari bahwa shalat harus dilaksanakan dalam kondisi apapun karena shalat adalah bentuk pengabdian seorang hamba kepada Tuhannya (Khalik).

Di antara semua kewajiban dalam Islam, shalat adalah yang tertinggi kedudukannya dan paling pokok. Perintah shalat diulang-ulang di beberapa ayat alQur'an dan hadis. Shalat merupakan tiang agama dan tidak boleh ditinggalkan oleh siapapun, dalam kondisi apapun. Keringanan shalat hanya pada tekhnis pelaksanaannya. Orang yang sakit berat tetap berkewajiban shalat dengan cara semampunya (Moh. Ali Aziz, 2015: 75).

Dalam menyampaikan materi motivasi beragama, pemateri memberikan wawasan dan kesadaran akan pentingnya ibadah shalat dalam Islam. Shalat bukan saja sebagai ibadah utama dan tiang agama, melainkan juga amalan yang paling menentukan bagi amalan-amalan yang lainnya. Amalan shalat adalah yang paling pertama dihisab kelak, dan menjadi garansi bagi diterima atau tidaknya amalan-amalan lain di hadapan Allah Swt. Pemateri menyampaikan dengan menggunakan bahasa anak-anak dengan mencontohkan apa yang sudah ditonton oleh anak-anak mengenai sosok Delisa. Delisa tetap rajin menghapal bacaan shalat dan melaksanakan shalat walaupun dia sudah cacat sejak kejadian tsunami.

Pentingnya ibadah shalat menuntut setiap muslim sejak anak-anak memperhatikan dengan sungguhsungguh berbagai ketentuan yang menyertai perintah shalat itu, antara lain menyangkut syarat sahnya shalat. Dengan mengutip dasar dari sumber alQuran dan hadis, pemateri menjelaskan bahwa sah dan sempurnanya ibadah shalat ditentukan oleh sah dan sempurnanya wudhu' atau tayammum. Karena itu setiap mushalli diwajibkan berwudhu atau tayammum dengan sempurna sebelum shalat. Karena itu materi bimbingan ibadah yang diberikan meliputi: wudhu', tayammum, shalat khususnya gerakan shalat dan bacaan shalat itu sendiri.

Sebagaimana tujuannya untuk memberikan pengetahuan dan kesadaran nyata dalam beribadah, maka bimbingan ini tidak semata-mata diberikan dalam bentuk ceramah, melainkan lebih banyak dalam bentuk praktek langsung, dalam hal ini anak-anak diajarkan untuk melaksanakan wudhu dan tayammum serta melafalkan bacaan shalat, terlebih dahulu mereka menonton film Hapalan Shalat Delisa. Setelah itu pemateri bertanya kepada anak-anak "siapa yang sudah hapal bacaan shalat?", mulai dari 
bacaan doa iftitah, ruku, sujud, duduk di antara dua sujud, tahiyyat awal dan tahiyat akhir. Bagi anak-anak yang sudah hapal, diminta untuk melafalkannya. Terakhir pemateri dan anak-anak melafalkannya bersama-sama. Begitulah seterusnya sampai anak-anak dianggap memahami dan menguasai materi motivasi beragama yang diberikan.

\section{Dakwah melalui wasilah tulisan}

Dakwah melalui wasilah tulisan termasuk dalam kategori dakwah bi alqalam (dakwah dengan karya tulis) (Moh.

Ali Aziz, 2009: 374). Hal yang mempengaruhi efektivitas tulisan adalah: bahasa, jenis huruf, format, penulis dan isi tulisannya. Bentuk tulisan juga bermacam-macam bentuknya, tulisan ilmiah, tulisan lepas, tulisan stiker, tulisan spanduk, tulisan sastra, tulisan terjemah, tulisan berita dan tulisan cerita.

Wasilah tulisan digunakan dai dalam berdakwah terhadap anak-anak pemulung dengan cara dai meminta anak-anak mengekspresikan kegemberian dan kesedihan. Setiap anak diberi kebebasan memilih gambar ekspresi senang atau sedih. Setelah itu anak-anak menulis sesuai dengan gambar ekspresi pilihannya. Dai yang menggunakan media ini adalah ustazah Juniawati sekretaris Jurusan Komunikasi Penyiaran Islam (KPI) Fakultas Ushuluddin Adab dan Dakwah (FUAD) IAIN Pontianak. Tema dakwah yang disampaikan mengenai akhlak.
Salah satu tulisan yang mengungkapkan ekspresi kesedihan dapat dilihat sebagai berikut:

"Pada bulan puasa kemarin tepatnya 24 Juni 2016 puasa ke 19 ayah tercintaku meninggalkan saya dan mama saya. Beliau meninggalkan kami sekeluarga di kampong halamannya. Beliau sakit ginjal yang sudah tidak bisa berfungsi lagi. Oleh karena itu, beliau meninggalkan kami sekeluarga. Banyak kenang-kenangan yang tidak bisa terlupakan sama ayahku. Beliau meninggalkanku semasa saya kelas 3 SMP. Beliau belum bisa melihatku sukses. Tapi saya akan buat mama saya bahagia. Dan saya dipesan agar saya harus rajin belajar sebelum ayah saya meninggal. Saya sangat sayang sama ayah saya tapi Allah Swt sudah mengambilnya duluan. Ayah yang sangat baik selalu menjagaku dan merawatku sampai saya besar. Ayah saya meninggalkan saya dan mama untuk selama-lamanya. Saya selalu berdoa agar ayahku bisa masuk surga. Ayah yang tenang ya di alam sana, anakmu ini selalu berdoa agar ayah tenang dan masuk surga. Saya sayang dengan Ayah I love ayah dan I miss you ayah."

Begitulah gambaran di atas yang menjelaskan tentang kesedihan seorang anak yang dituangkan dalam goresan pena mereka. Ada juga beberapa anak yang belum bisa mengekspresikan keberadaan mereka melalui tangis, senyum dan tawa. Mereka ini adalah anak-anak yang masih duduk di tingkat TK dan SD. Sehingga pemateri dan tim peneliti mengajari mereka huruf abjad dan mereka mengikuti tulisan yang dibuat. 
3. Dakwah melalui wasilah visual dan demonstratif

Wasilah visual digunakan dai dalam membahas tentang ciptaan Tuhan. Dalam hal ini dai menampilkan gambar ciptaan Tuhan berupa makhluk binatang gajah dan semut yang diberikan dalam rangkaian pelaksanaan dakwah pada anak-anak pemulung di Surau Ikhwanul Muslimin. Materi ini merupakan permintaan dari anak-anak dimana materi Ciptaan Tuhan disampaikan dengan menggunakan Bahasa Inggris. Karena itu materi bimbingan ini disampaikan oleh Ustadzah Nurmi AR, yang latar belakang pendidikan S1 dan S2 nya dari jurusan Bahasa Inggris dan sekaligus sebagai Sekretaris Jurusan IImu Al-Quran dan Tafsir Fakultas Ushuluddin Adab dan Dakwah IAIN Pontianak.

\section{Gambar:}

Pelaksanaan Dakwah dengan Tema Ciptaan Tuhan ${ }^{15}$

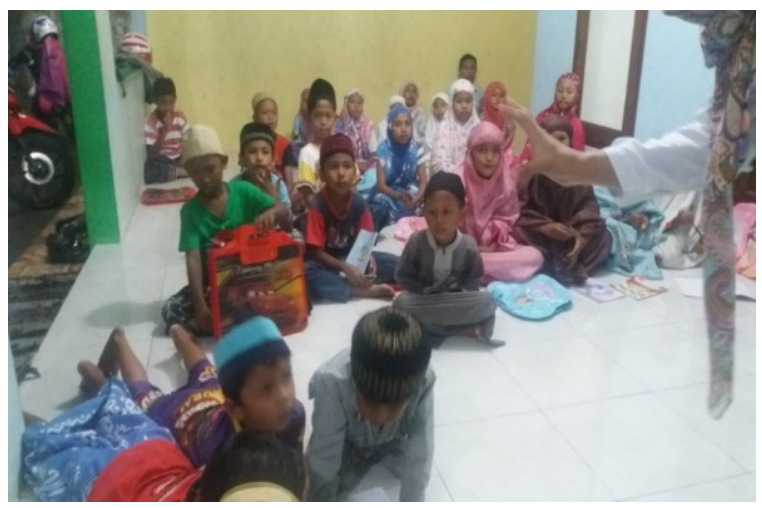

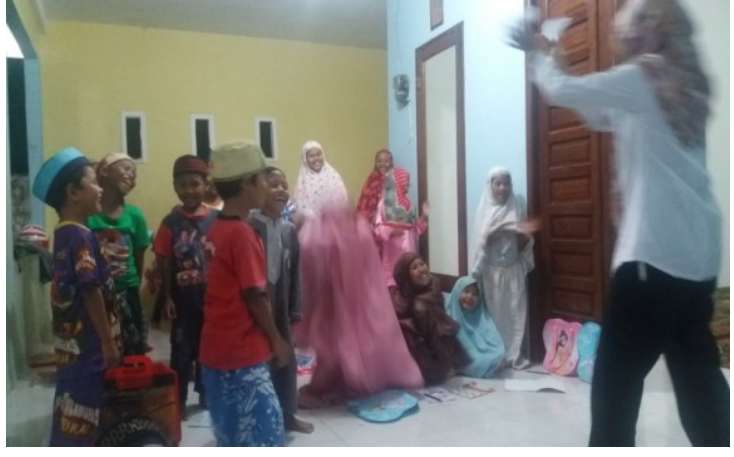

Sumber: Dokumen Pelaksanaan Dakwah, 2016

Sesuai dengan harapan anakanak, pemateri memberikan dakwahnya dengan menggunakan bahasa Inggris disertai dengan demontrasi gerakan, jadi anak-anak ikut bermain sesuai dengan kata-kata yang disebut oleh pemateri, sehingga pembelajaran bahasa Inggris sangat mudah dipahami anak-anak. Bahkan sehabis materi di atas, tim peneliti dan dai membahas tentang antusiasmenya anak-anak mengikuti kegiatan tersebut, dan begitu cepat mereka memahami. Jadi, ada sinergi antara anak-anak yang mudah memahami dan juga kemampuan dai menyampaikan materinya.

Hal ini menandakan bahwa anakanak pemulung tak bermasalah dalam menangkap materi yang diberikan selama ini. Permasalahan anak-anak hanya kondisi lingkungan yang tidak bersahabat dalam tumbuhkembangnya kehidupan religius mereka. Mereka berada pada

memperagakan gambar semut dengan cara duduk jongkok yang berarti semut itu kecil dengan menggunakan bahasa Inggris. 
problem situation (situasi bermasalah)

(Richard Nelson-Jones, 2012: 215).

Berdakwah melalui wasilah moral atau akhlak mendapat perhatian utama dalam pelaksanaan dakwah ini. Al-Quran diturunkan Tuhan kepada umat manusia sebagai suatu dokumen yang terus menekankan seluruh tarikan moral yang niscaya dalam laku kreatif manusia. perhatian utama al-Quran adalah manusia dan perbaikannya. Untuk itu, manusia mesti bergerak dalam kerangka tarikan moral tertentu yang diciptakan Tuhan dalam dirinya (Fazlur Rahman, 2016: 41).

Dalam kegiatan dakwah ini ada dua penekanan yaitu dai harus bermoral dan materi akhlak mendapat porsi lebih dibandingkan materi yang lainnya. Materi ini disampaikan oleh Patmawati sebagai kelanjutan dari bimbingan akhlak pertama (kejujuran) yang disampaikan oleh Ustadzah Juniawati. Materi ini lebih menggali lagi sifat anak-anak pemulung khususnya sifat-sifat mereka yang terpuji, karena sifat terpuji ini merupakan potensi yang harus dikembangkan oleh setiap anak. Pemateri hanya mendorong sifatsifat terpuji tersebut tetap terpelihara pada diri anak-anak terminal.

Dalam kesempatan ini, pemateri membagi-bagikan kertas kosong kepada anak-anak, kemudian anak-anak menggambar diri mereka masing-masing. Setelah itu, pemateri meminta mereka menulis sifat-sifat terpuji yang mereka miliki. Terakhir pemateri mengajak anakanak menulis juga sifat-sifat tercela yang biasa mereka lakukan.

Pentingnya materi akhlak ini disampaikan dalam dua sesi, mengingat anak-anak tersebut tumbuh dalam keluarga yang sibuk memenuhi sandang pangan mereka, bahkan ada di antara mereka ikut membantu orang tuanya bekerja. Jadi, pendidikan tertinggi di wilayah ini hanya sampai pada tingkat SMP setelah itu mereka harus bekerja untuk menyokong kehidupan keluarga mereka, sehingga angkatan anak pekerja masih banyak di wilayah ini.

Hal ini dapat diketahui berdasarkan observasi, wawancara dan juga catatan anak-anak mengenai sifatsifat mereka yang terpuji dan tercela, di antaranya, ungkapan berikut:

"Sifat terpuji: membantu orang tua, memberikan sedekah kepada orang yang tidak mampu, rajin membaca dan menulis. Sifat tercela: mencuri, berbohong dan membantah orang tua". 


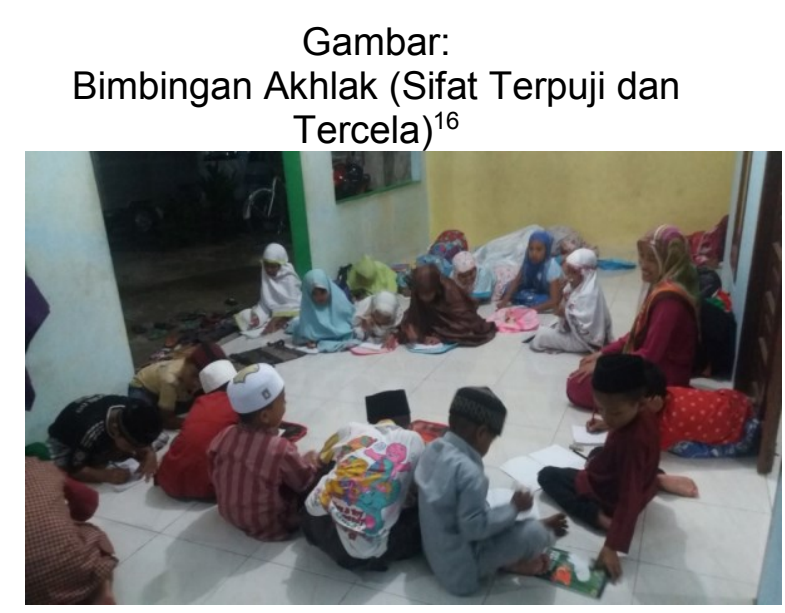

Keterangan: Suasana anak-anak peserta Kegiatan keagamaan.

Di antara anak-anak ada yang mengutarakan bahwa sifat tercela mereka adalah suka menyontek, itu terbukti dengan sendirinya, ketika tim peneliti kegiatan dakwah mengumpulkan hasil tulisan gambar dan tulisan mereka. Ada beberapa yang sama.

Kegiatan ini dianggap sangat menarik perhatian dari anak-anak, antusiasme mereka begitu terlihat, ada yang pandai menggambar dirinya, ada juga yang menggerutu dan mengatakan kepada tim "bu, kami sulit menggambar diri kami sendiri". Tapi akhirnya mereka menggambar semua dan mengemukakan sifat-sifat mereka yang terpuji dan tercela kecuali anak-anak yang duduk di bangku TK, mereka menggambar diri dengan gambar yang lucu.

\section{Kesimpulan}

Sebagai satu kesimpulan dari penelitian pelaksanaan dakwah keagamaan pada anak-anak pemulung Waduk Permai melalui media dakwah di Surau Ikhwanul Muslimin Kota Pontianak, didapatkan beberapa poin penting sebagai berikut:

1. Kegiatan dakwah keagamaan melalui wasilah ini dilakukan pada anak-anak pemulung yang ada di Waduk Permai, Kota Pontianak.

2. Kegiatan dakwah keagamaan melalui wasilah pada anak-anak pemulung dapat dilaksanakan dengan baik.

3. Secara substansi, kegiatan dakwah keagamaan melalui wasilah telah berhasil menumbuhkan semangat keagamaan, kemandirian sikap, kekompakan anak-anak dan kecintaan mereka terhadap ilmu pengetahuan agama Islam.

4. Pelaksanaan kegiatan dakwah keagamaan melalui wasilah pada anak-anak pemulung Waduk Permai juga telah mampu memberikan semangat dan perhatian dari para pemerhati dakwah Islam di dunia kampus khususnya IAIN Pontianak sebagai kampus negeri yang berorietasi agama.

anak-anak menulis sendiri mengenai sifat terpuji dan tercela mereka.
16 Patmawati yang sedang memberikan materi akhlak mengenai sifat terpuji dan tercela dengan menggunakan media tulis, 


\section{Daftar Pustaka}

Amrullah Ahmad, 1989, Dakwah dan

Transformasi Sosial Budaya,

Yogyakarta, LP2PM

Departemen Agama RI. 1983, Al-Quran dan Terjemahan, Jakarta.

Dindin Solahudin, 2004, Komunikasi \& Penyiaran Islam, 2004, Bandung: Benang Merah Press.

Fazlur Rahman, 2016 Islam Sejarah Pemikiran dan Peradaban, Bandung: Mizan.

Harjani Hefni dkk. 2006, Metode Dakwah, Jakarta: Prenada Media.

Harjani Hefni, 2014, Komunikasi Islam, Pontianak: IAIN Press.

Jamaluddin Kaffie, 1993, Psikologi Dakwah, Surabaya, Ofset Indah.

Moh. Ali Aziz, 2004, Ilmu Dakwah, Jakarta: Kencana 2009, IImu Dakwah, (edisi revisi), Jakarta: Kencana.

2015, 60 Menit Terapi

Shalat Bahagia, Surabaya: Duta Aksara Mulia.

M. Arifin, 1977, Psikologi Dakwah Sebuah Pengantar, Jakarta, Bulan Bintang.

M. Edi Kurnanto, 2015, Bimbingan \& Konseling Keagamaan, Pontianak: IAIN Pontianak Press.

Muhammad Munir dan Wahyu Ilaihi, 2009, Manajemen Dakwah, Jakarta: Kencana.

Munawar M. Saad, 2013, Dasar-dasar IImu Dakwah, Pontianak: STAIN Pontianak Press,
Nurcholish Madjid, 1983, Aspirasi Umat Islam Indonesia, Jakarta: Leppenas.

Philip K. Hitti, 1974, History of the Arabs, Jakarta: Serambi IImu Semesta.

Richard Nelson-Jones, 2012. Pengantar Keterampilan Konseling, Yogyakarta: Pustka Pelajar.

Samsul Munir Amin, 2014, Sejarah Dakwah, Jakarta: AMZAH.

Siti Muriah, 2000, Metodologi Dakwah Kontemporer, Yogyakarta: Mitra Pustaka.

Tata Sukayat, 2015, IImu Dakwah, Bandung: Remaja Rosdakarya.

Toha Yahya Umar, 1979, IImu Dakwah, Jakarta: Wijaya.

Wahyu Ilaihi dan Harjani Hefni, 2007, Pengantar Sejarah Dakwah, Jakarta: Rahmat Semesta.

W.J.S. Poerwadarminta, 1979, Kamus Umum Bahasa Indonesia, Jakarta, Balai Pustaka 